\title{
Mineral Fertilizer Microdosing Alone or Combined with Urea on Maize and According to the Soil Chemical Elements Variation (Thies, Senegal)
}

\author{
Rabi Housseini Malam Laminou ${ }^{1}$, Saliou Ndiaye ${ }^{2}$, Djibril Diallo ${ }^{2}$, Aliou Badara Dieye ${ }^{3}$, \\ Mariama Dalanda Diallo ${ }^{4,5,6}$, Aliou Guisse ${ }^{1,5,6, *}$ \\ ${ }^{1}$ Department of Plant Biology, Science and Technique Faculty, Cheikh Anta Diop University (UCAD), Dakar, Senegal \\ ${ }^{2}$ Departement of Plant Biologie, National School of Agriculture of Thies (ENSA), University of Thies, Thies, Senegal \\ ${ }^{3}$ National Institute of Pedology (INP), Dakar, Senegal \\ ${ }^{4}$ Departement of Plant Production/ UFR of Agronomic Sciences, Aquaculture and Food Technologies, Gaston Berger University, Saint Louis, \\ Senegal \\ ${ }^{5}$ UMI 3189 "Environnement, Santé, Sociétés" UGB, UCAD, CNRS, CNRST, USTTB, Dakar, Senegal \\ ${ }^{6}$ Observatoire Homme-Milieux International de Téssékéré, CNRS/Cheikh Anta Diop University, Dakar, Senegal
}

Email address:

housseini_rabi@yahoo.fr (R. H. M. Laminou), salioundiaye@orange.sn (S. Ndiaye),djidials@yahoo.fr (D. Diallo), rossbea7@hotmail.com (A. B. Dieye),mariama-dalanda.diallo@ugb.edu.sn (M. D. Diallo), aliou.guisse@ucad.edu.sn (A. Guissé)

${ }^{*}$ Corresponding author

\section{To cite this article:}

Rabi Housseini Malam Laminou, Saliou Ndiaye, Djibril Diallo, Aliou Badara Dieye, Mariama Dalanda Diallo, Aliou Guisse. Mineral Fertilizer Microdosing Alone or Combined with Urea on Maize and According to the Soil Chemical Elements Variation (Thies, Senegal). American Journal of Agriculture and Forestry. Vol. 8, No. 3, 2020, pp. 69-76. doi: 10.11648/j.ajaf.20200803.13

Received: May 18, 2020; Accepted: June 1, 2020; Published: June 8, 2020

\begin{abstract}
Mineral fertilizer microdosing is a technique developed not only to compensate for the low availability of mineral fertilizers but also to optimize their removal by the crop. A microdose experiment on a maize crop (rainfed) was conducted at The Center for Application of Agricultural Techniques (CATA) of the National School of Agriculture of Thies (ENSA). The aim of this experiment was to evaluate the effect of 15-15-15 (NPK) mineral fertilzer microdosing on maize production and on the variation of soil chemical elements. The experimental set-up was a Split plot with three replicates. An absolute control, one extension dose and six microdoses derived from the combination of three doses of 15-15-15 (NPK) mineral fertilizer ( $2 \mathrm{~g}, 3 \mathrm{~g}$ and $4 \mathrm{~g}$ per pot) and two doses of urea (U) $(0 \mathrm{~g}$ and $2 \mathrm{~g}$ per pot) were tested on Sooror and Gwana maize varieties. The parameters studied were growth, yields, yield components and soil nutrients content. The results obtained show that the microdose had significant or very highly significant effects depending on the treatments on maize production. Fertilizer doses combining NPK and urea (NPKU) by microdose increased maize production compared to the control and extension dose. At the NPK3U dose, the microdose increased grain yield by $132 \%$ to $36 \%$ compared to the control and extension dose, respectively. Compared to the control, soil pH decreased at all doses. All treatments resulted in a decrease in soil nitrogen content, except for the NPK4U rate. Soil phosphorus and potassium levels showed positive rates of change compared to the control. The NPK2U treatment, which had comparable grain yield to the NPK3U treatment and an acceptability index of 1.8, is most recommended.
\end{abstract}

Keywords: Microdose, NPK, Urea, Corn, Treatement, Thies

\section{Introduction}

The increase in population pressure has led to an intensification of agricultural practices and an extension of cultivated areas resulting in a reduction in fallow time. This situation not only predisposes the soil to erosion, but also leads to a decline in soil fertility [1]. Low soil fertility is one of the constraints limiting agricultural production and justifying the effectiveness of mineral fertilizers on crop yields. Indeed, yield levels are generally higher in countries 
where fertilizer consumption is high [2]. Fertilizer use is therefore a key factor in improving crop yields. However, the application of mineral fertilizers is extremely limited in the Sahel because of their low availability, very high costs, the low investment capacity of most farmers and the economic risks due to climatic hazards [3]. Their consumption in Africa is much lower than $10 \mathrm{~kg} / \mathrm{ha} /$ year, whereas 5 to 10 times more would be necessary to reach a level of productivity that would allow the achievement of food self-sufficiency [4]. Fertilization techniques likely to increase yields while minimizing costs should therefore be developed.

The technique of applying mineral fertilizer to the pot, commonly known as microdosing, is designed to minimize the investment in fertilizer while optimizing productivity. It consists of applying small quantities of fertilizer (less than or equal to $6 \mathrm{~g}$ depending on the type of fertilizer and the type of crop) to each bunch of a given crop, as opposed to conventional broadcast or in-line applications. This technology has proven to be effective in terms of productivity on different types of soil and crops. However, investigations in this area have focused more on millet and sorghum.

This study aims to evaluate the effects of 151515 (NPK) microdosing mineral fertilizer alone or in combination with urea on maize production and on some soil chemicals.

\section{Materials and Methods}

\subsection{Presentation of the Study Area}

The experiment was conducted at the Center for Application of Agricultural Techniques (CATA) of the National School of Agriculture (ENSA) of Thies $\left(14^{\circ} 46^{\prime} \mathrm{N}\right.$ and $\left.16^{\circ} 57^{\prime} \mathrm{W}\right)$ located $4 \mathrm{~km}$ from Thiès on the road to Khombole (figure 1).

The climate of this locality is characteristic of the Sahelian zone [5] with two well contrasted seasons: a rainy season from June to October, with a uni-modal distribution and whose maximum is between August and September [6], and a dry season from November to May. Annual rainfall is relatively low, between 300 and $500 \mathrm{~mm}$. Average temperatures range from $19{ }^{\circ} \mathrm{C}$ in the cool season to $40{ }^{\circ} \mathrm{C}$ in the hot dry season [7].

The soil in this region is of the "dek-dior" type, which is characteristic of ferruginous soils that have been lightly leached. It is a poorly evolved type of soil, made up of successive deposits of sandy materials with low clay and silt content and poor fertility [8].

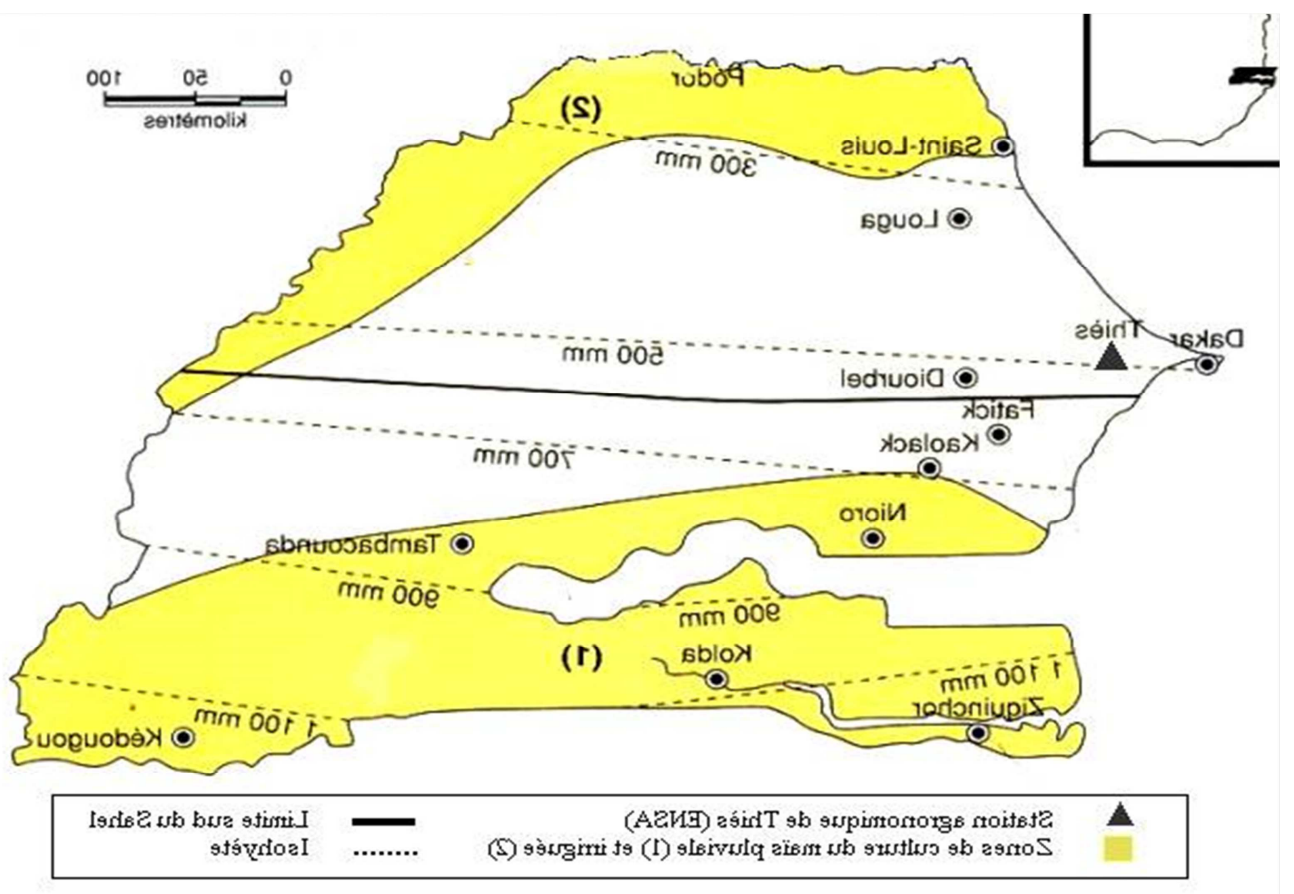

Figure 1. Location of the study site, maize-growing area and cumulative rainfall (1950-1997) in Senegal, [9].

\subsection{Plant Material}

The plant material used is composed of two maize varieties: Gwana (VG) and Sooror (VR).

1. Gwana is a rainfed crop (Fatick, Kaolack), with a short cycle (75-80 days after sowing (JAS)). The kernels are white in colour with a toothed horny texture. Its yield potential is $2 \mathrm{t} / \mathrm{ha}$.

2. Sooror is a rainfed crop (south of Thies, Kaolack, Fatick), with a short cycle (75-80 days after sowing). The grains are yellow in colour with a horny-toothed texture. Its main characteristics are: resistance to helminthosporiosis, resistance to lodging and stem breakage. Its grain yield potential is $2 \mathrm{t} / \mathrm{ha}$.

\subsection{Methods}

\subsubsection{Experimental Design}

The trial was conducted using a three-repeat split plot design. Each replicate consisted of two sub-blocks of 8 elementary plots of $3 \mathrm{~m} \times 2 \mathrm{~m}$, i.e. a total of 48 plots for the whole system. The alleys are $2 \mathrm{~m}$ between the blocks and $1.5 \mathrm{~m}$ between the 
sub-blocks. The elementary plots, separated by $0.5 \mathrm{~m}$ alleys, have six rows of 11 bunches each, i.e. 66 bunches per plot.

The factors studied are:

1. the variety with two levels: Gwana (VG) and Sooror (VR),

2. and fertilizer (NPK 15-15-15 and Urea 46\%) with eight levels (Table 1).

Table 1. Experienced treatments.

\begin{tabular}{ll}
\hline Treatments & Quantity/ha \\
\hline T0 & $0 \mathrm{~kg} / \mathrm{ha}$ \\
DV & $200 \mathrm{~kg} / \mathrm{ha}$ of NPK $+150 \mathrm{~kg} /$ ha of urea \\
NPK2 & $166.6 \mathrm{~kg} / \mathrm{ha} \mathrm{NPK} \mathrm{i.e.} 2 \mathrm{~g} / \mathrm{package}$ \\
NPK2U & NPK2 $\mathrm{associated}$ with $166.6 \mathrm{~kg} / \mathrm{ha}$ of urea, i.e. $2 \mathrm{~g} /$ poquet \\
NPK3 & $249.9 \mathrm{~kg} /$ ha of NPK, i.e. $3 \mathrm{~g} / \mathrm{package}$ \\
NPK3U & NPK3 associated with $166.6 \mathrm{~kg} /$ ha of urea, i.e. $2 \mathrm{~g} /$ poquet \\
NPK4 & $333.3 \mathrm{~kg} /$ ha of NPK, i.e. $4 \mathrm{~g} / \mathrm{plot}$ \\
NPK4U & NPK4 combined with $166.6 \mathrm{~kg} /$ ha of urea, i.e. $2 \mathrm{~g} /$ poquet \\
\hline
\end{tabular}

Fertilizer was applied in two stages:

1. the NPK was applied at the time of sowing: once the packet was opened, the doses of NPK were first applied, then the maize grains were applied, taking care to avoid any contact with the NPK. Indeed, contact between the NPK and the corn kernels could cause the grains to burn.

2. The urea was applied after the sorting of the plants at the 6-10 leaf stage in a localized manner at the base of the pot.

\subsubsection{Growth Parameters}

They are made on the six poquets of the two central lines of each elementary plot with jumps of 4 poquets on the front and back ends of each line. These measurements concerned the height of the plants, the diameter of the stem at the collar and the height of insertion of the ear. The height of the plants was measured weekly from the 22nd day after sowing (JAS) and the height of the ear insertion at the 80th JAS (maturity), using a graduated ruler. The diameter of the stem at the collar was measured with a calliper at the 64th JAS.

\subsubsection{Yield Parameters}

Yield measurements and yield parameters are made on the 20 plants in the four central rows of each elementary plot with jumps of 3 plants on the front and back ends of each row. The ears of the 20 plants were first harvested, put into labelled bags and transported to the laboratory for drying. The dry biomass (DSB) was weighed on site. After drying, the following were determined: grain yield, number of ears per plant, dry ear weight, number of rows per ear, number of grains per ear, and 100-grain weight.

\subsubsection{Soil Sampling and Analysis}

Soil samples were taken at a depth of $0-20 \mathrm{~cm}$, at the beginning of the campaign before sowing and at the end of the campaign after harvesting for the determination of physical and chemical parameters.

Before sowing, the samples were taken on the diagonal of the entire site and mixed to form a composite sample. After harvesting the samples were taken from the plots; a composite was formed from three samples from each elementary plot. A total of 48 samples were taken after harvest and one before sowing. After drying, these samples were analysed at the soil laboratory of the National Institute of Pedology in Dakar.

\subsubsection{Economic Analysis of Treatments}

In order to identify the best treatment that could be easily adopted by the grower, an acceptability index (AI) was calculated. It compares the cost-effectiveness of a treatment to the control treatment. It is therefore the ratio of the benefits of the two treatments: $\mathrm{AI}=$ treatment benefit/control benefit. Thus a technology can only be easily adopted when the value of AI is equal to or greater than 2. Adoption is reluctant if this value is between 1.5 and 2; and below 1.5 there is rejection.

\subsubsection{Statistical Analysis}

The collected data were entered with the Excel spreadsheet version 2013 and then processed using the statistical software GenStat 15 th edition. The analysis of variance and the lsd test (low significant difference, at the 5\% threshold) were used to compare the mean results of the observed variables; for the separation of the means, this was done with the DUNCAN test at the $5 \%$ threshold.

\section{Results}

\subsection{Initial Physico-chemical Characteristics of the Experimental Plot Soil}

The results of the analysis of soil samples taken from the site before the test was installed in the surface horizon at a depth of $20 \mathrm{~cm}$ (Table 2) show that the soil has a grain size dominated by sands (48.28\%) and silts (48.2\%) giving it a sandy-silt type texture. The $\mathrm{pH}$ of 7.5 indicates a slightly alkaline soil. With regard to its CEC (14 meq/100g), this soil has a low potential for element exchange. Its organic matter content is also very low, but the $\mathrm{C} / \mathrm{N}$ ratio (10) indicates that it is poorly mineralized. Nitrogen and phosphorus contents are low. The ion procession is poor and the low cation capacity is largely explained by the low organic matter and clay content.

Table 2. Initial physico-chemical characteristics of the soil.

\begin{tabular}{ll}
\hline Granulometry (\%) & \\
\hline Clay & 3.52 \\
Limons & 48.2 \\
Sandy & 48.28 \\
Chemical elements & \\
pHeau & 7.5 \\
$\mathrm{C} \%$ & 0.55 \\
$\mathrm{~N} \%$ & 0.05 \\
$\mathrm{C} / \mathrm{N}$ & 10 \\
$\mathrm{P}$ ppm & 0.64 \\
$\mathrm{~K}$ meq/100g & 0.36 \\
$\mathrm{Ca}$ meq/100g & 3.75 \\
$\mathrm{Mg}$ meq/100g & 2.25 \\
Na meq/100g & 0.33 \\
$\mathrm{CEC}$ meq/100g & 14 \\
\hline
\end{tabular}

\subsection{Influence of the Variety on Maize}

For all parameters measured, the variety Gwana (VG) 
recorded the highest averages with significant differences in ear insertion height, 100 kernel weight, ear weight and kernel

yield (Table 3 ).

Table 3. Influence of the variety on maize.

\begin{tabular}{llllllllll}
\hline Varieties & HP & DTC & HIE & NGE & NRE & Weight 100 grains & weight ears & grain yield & BMS \\
\hline VG & $112.5 \mathrm{a}$ & $14.8 \mathrm{a}$ & $76.17 \mathrm{a}$ & $303.93 \mathrm{a}$ & $13.36 \mathrm{a}$ & $23.54 \mathrm{a}$ & $86.41 \mathrm{a}$ & $3640 \mathrm{a}$ & $3949.31 \mathrm{a}$ \\
VR & $104.6 \mathrm{a}$ & $14.34 \mathrm{a}$ & $69.84 \mathrm{a}$ & $288.82 \mathrm{a}$ & $12.79 \mathrm{a}$ & $20.58 \mathrm{a}$ & $72.63 \mathrm{a}$ & $2984 \mathrm{a}$ & $3525.70 \mathrm{a}$ \\
Fpr & 0.38 & 0.27 & 0.014 & 0.30 & 0.10 & $<.001$ & 0.01 & 0.011 & 0.39 \\
LSD & 30.24 & 0.84 & 4.964 & 29.40 & 0.691 & 1.34 & 10.1 & 493.68 & 1596.8 \\
\hline
\end{tabular}

Averages affected by the same letter in the same column are not significantly different at the $5 \%$ threshold

\subsection{Effect of Treatments on Growth}

The treatments significantly affected growth parameters (Table 4). The control treatment recorded the lowest means of the growth parameters. The highest growth parameter averages were obtained with the combined microdosed NPK and urea treatments.

For height (HP), the means increase with NPK doses and are $117 \mathrm{~cm}, 118.1 \mathrm{~cm}$ and $125.7 \mathrm{~cm}$ for NPK2U, NPK3U and NPK4U, respectively. However, these averages are not significantly different from the average obtained with the NPK4 treatment providing NPK alone by microdose.

Variations in stem-to-collar diameter (DTC) followed the same trends as those in plant height. DTC increased with increasing doses of NPK combined with microdosed urea. The NPK4U dose recorded the largest mean $(16.11 \mathrm{~cm})$, followed by the NPK3U dose $(15.60 \mathrm{~cm})$ and the NPK2U dose $(15.03$ $\mathrm{cm})$. However, the difference was not significant with the NPK4, NPK3 and DV doses.

With respect to the height of ears insertion (HIE), the highest averages are $80.53 \mathrm{~cm}$ for the NPK2U dose, $79.62 \mathrm{~cm}$ for the NPK3U dose and $78.31 \mathrm{~cm}$ for the NPK4U dose, respectively. However, the latter are not significantly different from the averages obtained with the NPK2, NPK3 and NPK4 doses.

Table 4. Effect of treatments on growth parameters.

\begin{tabular}{llll}
\hline Treatements & Height & collar diameter & ears insertion \\
\hline T0 & $79.0 \pm 8.68 \mathrm{a}$ & $12.70 \pm 0.81 \mathrm{a}$ & $55.58 \pm 5.35 \mathrm{a}$ \\
DV & $101.2 \pm 6.99 \mathrm{~b}$ & $14.97 \pm 0.50 \mathrm{bc}$ & $68.26 \pm 4.43 \mathrm{~b}$ \\
NPK2U & $117.0 \pm 10.78 \mathrm{~cd}$ & $15.03 \pm 0.48 \mathrm{c}$ & $80.53 \pm 4.93 \mathrm{c}$ \\
NPK2 & $104.8 \pm 9.73 \mathrm{bc}$ & $13.29 \pm 0.67 \mathrm{ab}$ & $75.49 \pm 3.51 \mathrm{bc}$ \\
NPK3U & $118.1 \pm 8.25 \mathrm{~cd}$ & $15.60 \pm 0.67 \mathrm{c}$ & $79.62 \pm 4.99 \mathrm{c}$ \\
NPK3 & $109.5 \pm 22.21 \mathrm{bc}$ & $14.26 \pm 1.25 \mathrm{abc}$ & $73.93 \pm 8.77 \mathrm{bc}$ \\
NPK4U & $125.7 \pm 6.61 \mathrm{~d}$ & $16.11 \pm 0.81 \mathrm{c}$ & $78.31 \pm 5.12 \mathrm{bc}$ \\
NPK4 & $113.1 \pm 13.09 \mathrm{bcd}$ & $14.60 \pm 0.73 \mathrm{bc}$ & $72.31 \pm 5.32 \mathrm{bc}$ \\
LSD & 13.60 & 1.666 & 9.248 \\
Fprob & $<.001$ & 0.005 & $<.001$ \\
\hline
\end{tabular}

Averages with the same letter in the same column are not significantly different at the $5 \%$ threshold \pm Standard error

\subsection{Effect of Treatments on Yield Parameters}

Table 5 shows the effect of treatments on yield parameters. The analysis of variance of the number of grains per ear (NGE) shows significant differences between treatments $(\mathrm{Fpr}<5)$. The control treatment recorded the lowest NGE (234). The highest mean NGEs were obtained with the treatments combining NPK and Urea; these were NPK3U (333.6),
NPK4U (329.6), DV (322.9), respectively. Nevertheless, these means do not differ significantly from those obtained with treatments providing NPK alone (NPK2, NPK3 and NPK4). For the number of rows per ear (NRE), ear weight and 100 kernel weight, the analysis of variance did not show significant differences between treatments.

Table 5. Effect of treatments on yield parameters.

\begin{tabular}{lllll}
\hline Treatements & NGE & NRE & Weight ears (g) & Weight 100grains (g) \\
\hline T0 & $235.4^{\mathrm{a}} \pm 40.78$ & $12.50^{\mathrm{a}} \pm 0.82$ & $62.36^{\mathrm{a}} \pm 12.62$ & $21.51^{\mathrm{a}} \pm 1.76$ \\
DV & $322.9^{\mathrm{b}} \pm 15.31$ & $13.00^{\mathrm{a}} \pm 0.40$ & $88.62^{\mathrm{b}} \pm 6.60$ & $22.13^{\mathrm{a}} \pm 0.93$ \\
NPK2U & $285.8^{\mathrm{ab}} \pm 16.89$ & $12.56^{\mathrm{a}} \pm 0.45$ & $77.30^{\mathrm{ab}} \pm 2.70$ & $22.31^{\mathrm{a}} \pm 0.81$ \\
NPK2 & $268.8^{\mathrm{ab}} \pm 28.37$ & $12.67^{\mathrm{a}} \pm 0.74$ & $71.73^{\mathrm{ab}} \pm 10.59$ & $21.12^{\mathrm{a}} \pm 1.79$ \\
NPK3U & $333.6^{\mathrm{b}} \pm 22.94$ & $13.83^{\mathrm{a}} \pm 0.64$ & $92.17^{\mathrm{b}} \pm 9.03$ & $22.30^{\mathrm{a}} \pm 1.28$ \\
NPK3 & $297.3^{\mathrm{ab}} \pm 17.21$ & $13.44^{\mathrm{a}} \pm 0.72$ & $77.68^{\mathrm{ab}} \pm 0.72$ & $22.01^{\mathrm{a}} \pm 1.92$ \\
NPK4U & $329.6^{\mathrm{b}} \pm 28.65$ & $13.28^{\mathrm{a}} \pm 0.39$ & $83.83^{\mathrm{ab}} \pm 0.39$ & $23.04^{\mathrm{a}} \pm 1.84$ \\
NPK4 & $297.7^{\mathrm{ab}} \pm 32.95$ & $13.33^{\mathrm{a}} \pm 0.97$ & $82.49^{\mathrm{ab}} \pm 0.97$ & $22.04^{\mathrm{a}} \pm 1.64$ \\
LSD & 59.799 & 1.350 & 19.381 & 2.275 \\
Fpr & 0.033 & 0.422 & 0.087 & 0.808 \\
\hline
\end{tabular}

Averages with the same letter in the same column are not significantly different at the $5 \%$ threshold 


\subsection{Effect of Treatments on Grain Yield and Total Dry Biomass}

The analysis of variance on grain yield shows very highly significant differences (Table 6). Grain yields are higher with NPK2U, NPK3U, NPK4U treatments, combining NPK and urea by microdose. The control treatment $(1811 \mathrm{~kg} / \mathrm{ha})$ recorded the lowest grain yield. The highest grain yield (4193 $\mathrm{kg} \cdot \mathrm{ha}^{-1}$ ) was obtained with the NPK3U rate. However, this is not significantly different from those obtained with the NPK3 and NPK4 doses. The total dry biomass (DB) was also significantly affected by the treatments. Total dry biomass varied from $2466.3 \mathrm{~kg} / \mathrm{ha}$ to $4301.9 \mathrm{~kg} / \mathrm{ha}$. The highest biomass was obtained with the NPK4U dose. However, this was not significantly different from that obtained with the NPK4U dose. The control treatment recorded the lowest total dry biomass.

Table 6. Effect of treatments on yields.

\begin{tabular}{lll}
\hline Treatements & Grains yields $(\mathbf{k g} / \mathbf{h a})$ & BMS $(\mathbf{k g} / \mathbf{h a})$ \\
\hline T0 & $1811^{\mathrm{a}} \pm 530.05$ & $2466.31^{\mathrm{a}} \pm 8.68$ \\
DV & $3079^{\mathrm{bc}} \pm 145.51$ & $3874.97^{\mathrm{b}} \pm 6.99$ \\
NPK2U & $3717^{\mathrm{bcd}} \pm 333.67$ & $3681.82^{\mathrm{b}} \pm 10.78$ \\
NPK2 & $2768^{\mathrm{ab}} \pm 449.58$ & $3673.49^{\mathrm{b}} \pm 9.73$ \\
\hline
\end{tabular}

\begin{tabular}{lll}
\hline Treatements & Grains yields $(\mathbf{k g} / \mathbf{h a})$ & BMS $(\mathbf{k g} / \mathbf{h a})$ \\
\hline NPK3U & $4193^{\mathrm{d}} \pm 589.65$ & $3922.82^{\mathrm{b}} \pm 8.25$ \\
NPK3 & $3333^{\text {bcd }} \pm 707.67$ & $3785.54^{\mathrm{b}} \pm 22.21$ \\
NPK4U & $4062^{\text {cd }} \pm 329.02$ & $4301.88^{\mathrm{b}} \pm 6.61$ \\
NPK4 & $3530^{\text {bd }} \pm 747.75$ & $4185.22^{\mathrm{b}} \pm 13.09$ \\
LSD & 984.7 & 609.99 \\
Fprob & $<.001$ & $<.001$ \\
\hline
\end{tabular}

Averages with the same letter in the same column are not significantly different at the $5 \%$ threshold

\subsection{Interaction of Varieties and Treatments on Growth, Yield Parameters and Yields}

Variety*treatment interaction had no effect on maize behavior (Table 7). But nevertheless, the highest averages are obtained with the variety Gwana in the following cases:

1. in interaction with the NPK3U dose for plant height, height of ear insertion, number of grains per ear, ear weight and grain yield;

2. in interaction with the NPK4U dose for stem to crown diameter and total dry biomass;

3. and in interaction with the NPK3 dose, for the number of rows per ear and ear weight.

Table 7. Effect of Variety*Treatment Interaction on Maize.

\begin{tabular}{|c|c|c|c|c|c|c|c|c|c|c|}
\hline Varieties & Treatements & HP & DTC & HIE & NGE & NRE & $\begin{array}{l}\text { Weight } \\
100 \text { grains }\end{array}$ & Pds ears & $\begin{array}{l}\text { Grains } \\
\text { yields }\end{array}$ & BMS \\
\hline \multirow{6}{*}{ VG } & T0 & 82.9 & 13.19 & 60.06 & 247.56 & 13.11 & 23.38 & 69.77 & 2242 & 2694.10 \\
\hline & DV & 96.8 & 14.53 & 68.73 & 312.22 & 12.89 & 23.23 & 90.49 & 3218 & 3975.46 \\
\hline & NPK2U & 118.4 & 15.19 & 82.89 & 277.89 & 12.44 & 23.23 & 76.04 & 3648 & 3682.54 \\
\hline & NPK2 & 107.1 & 13.47 & 79.58 & 301 & 13.33 & 23.51 & 85.62 & 3302 & 4060.66 \\
\hline & NPK3U & 129 & 15.81 & 83.4 & 338.89 & 13.78 & 23.87 & 98.51 & 4671 & 3829.75 \\
\hline & NPK3 & 124.4 & 15.14 & 82.67 & 312.33 & 14.22 & 24.44 & 89.61 & 4263 & 3899.36 \\
\hline \multirow{9}{*}{ VR } & NPK4U & 125.3 & 16.23 & 75.33 & 337.33 & 13.33 & 24.25 & 94.42 & 3918 & 4773.97 \\
\hline & NPK4 & 116.3 & 14.89 & 76.67 & 304.22 & 13.78 & 22.37 & 86.86 & 3856 & 4678.63 \\
\hline & T0 & 75.2 & 12.22 & 51.11 & 223.22 & 11.89 & 19.64 & 54.95 & 1380 & 2238.52 \\
\hline & DV & 105.7 & 15.42 & 67.78 & 333.67 & 13.11 & 21.03 & 86.75 & 2940 & 3774.48 \\
\hline & NPK2U & 115.6 & 14.88 & 78.17 & 293.67 & 12.67 & 21.39 & 78.55 & 3786 & 3682.54 \\
\hline & NPK2 & 102.6 & 13.1 & 71.39 & 236.67 & 12 & 18.73 & 57.83 & 2234 & 3286.32 \\
\hline & NPK3U & 107.2 & 15.4 & 75.83 & 328.22 & 13.89 & 20.73 & 85.83 & 3715 & 4015.90 \\
\hline & NPK4U & 126.1 & 16 & 81.28 & 321.78 & 13.22 & 21.83 & 73.24 & 4206 & 3829.79 \\
\hline & NPK4 & 110 & 14.3 & 67.94 & 291.11 & 12.89 & 21.71 & 78.13 & 3203 & 3691.80 \\
\hline LSD & & 24.71 & 2.38 & 14.04 & 83.16 & 1.96 & 3.78 & 28.57 & 1396.35 & 1240.37 \\
\hline Fpr & & 0.144 & 0.893 & 0.465 & 0.872 & 0.731 & 0.732 & 0.793 & 0.423 & 0.397 \\
\hline
\end{tabular}

Averages with the same letter in the same column are not significantly different at the $5 \%$ threshold

\subsection{Effect of Fertilizer on Soil Chemical Variation}

The analysis of the effects of fertilizers on soil fertility focused on four decisive factors: $\mathrm{pH}$, for its influence on the plant's assimilability of soil nutrients, and nitrogen, phosphorus and potassium, which are the major elements that the plant needs for its growth and development in order to obtain good yields.

Table 8 shows the results of the soil chemical analyses at the end of the trial and the rates of change from the control for each element that occurred in the soil.

Soil chemistry ranged from 8.05 to $8.267 ; 0.05$ to 0.076 ;
0.54 to 2.53 and 0.272 to 0.380 for $\mathrm{pH}$, nitrogen, phosphorus and potassium respectively. The analysis of variance did not show significant differences between the treatments means of all chemical parameters considered. Compared to the control treatment, the $\mathrm{pH}$ of all treatments decreased (negative rate of change) and the potassium concentration of all treatments increased (positive rate of change). All treatments increased the phosphorus content, except for NPK2 and NPK3U. For nitrogen, only the NPK4U treatment had a positive rate of change. 
Table 8. Soil chemistry characteristics after the experiment and rate of change in soil treatments relative to the control.

\begin{tabular}{lllllllll}
\hline Treatements & $\mathbf{p H}$ & TV & $\mathbf{N}$ & TV & P & TV & K & TV \\
\hline T0 & 8.27 & - & 0.066 & - & 0.78 & - & 0.272 & - \\
DV & 8.11 & -0.15 & 0.064 & -0.002 & 0.87 & 0.09 & 0.339 & 0.067 \\
NPK2U & 8.15 & -0.11 & 0.061 & -0.005 & 2.43 & 1.65 & 0.363 & 0.091 \\
NPK2 & 8.11 & -0.15 & 0.055 & -0.011 & 0.54 & -0.24 & 0.380 & 0.108 \\
NPK3U & 8.13 & -0.13 & 0.064 & -0.002 & 0.64 & -0.14 & 0.277 & 0.005 \\
NPK3 & 8.05 & -0.21 & 0.050 & -0.016 & 1.01 & 0.23 & 0.330 & 0.058 \\
NPK4U & 8.11 & -0.15 & 0.076 & 0.010 & 1.92 & 1.14 & 0.311 & 0.039 \\
NPK4 & 8.18 & -0.04 & 0.050 & -0.016 & 0.93 & 0.15 & 0.373 & 0.101 \\
Fpr & 0.765 & - & 0.055 & - & 0.490 & - & 0.216 & - \\
LSD & 0.2386 & - & 0.0168 & - & 1.992 & - & 0.0983 & - \\
\hline
\end{tabular}

Averages with the same letter in the same column are not significantly different at the $5 \%$ threshold

\subsection{Economic Analysis of Treatments}

The acceptability index results presented in Table 9 show that NPK3U (IA=1.9), NPK4U (IA=1.8) and NPK2U (IA=1.8) treatments combining NPK and urea are the most cost-effective.

Table 9. Acceptability index for different treatments.

\begin{tabular}{|c|c|c|c|c|c|c|c|c|}
\hline Trea tements & $\begin{array}{l}\text { Cost } \\
\text { Of fertilizers }\end{array}$ & $\begin{array}{l}\text { Labour } \\
\text { force }\end{array}$ & $\begin{array}{l}\text { Total variables } \\
\text { cost }\end{array}$ & Grain yield & $\begin{array}{l}\text { Straw } \\
\text { yield }\end{array}$ & $\begin{array}{l}\text { Gross } \\
\text { income }\end{array}$ & $\begin{array}{l}\text { Gross } \\
\text { profit }\end{array}$ & $\begin{array}{l}\text { Acceptability } \\
\text { index }\end{array}$ \\
\hline T0 & 0 & 6000 & 6000 & 543300 & 49320 & 592620 & 586620 & \\
\hline DV & 145000 & 6000 & 151000 & 923700 & 77500 & 1001200 & 850200 & 1.4 \\
\hline NPK2U & 133280 & 9000 & 142230 & 1115100 & 73640 & 1188740 & 1046510 & 1.8 \\
\hline NPK2 & 83300 & 9000 & 92300 & 830400 & 73460 & 903860 & 811560 & 1.4 \\
\hline NPK3U & 174930 & 9000 & 183930 & 1239000 & 78460 & 1317460 & 1133530 & 1.9 \\
\hline NPK3 & 124950 & 9000 & 133950 & 999900 & 75720 & 1075620 & 941670 & 1.6 \\
\hline NPK4 & 166650 & 9000 & 175650 & 1059000 & 83700 & 1142700 & 967050 & 1.6 \\
\hline
\end{tabular}

\section{Discussions}

The results show that the variety Gwana had significant effects on the height of the ear insertion, ear weight, 100 kernel weight and kernel yield. And on the other hand that variety*dose interactions of mineral fertilizers did not have significant effects even though the highest averages of growth, yield and yield parameters were obtained with the Gwana variety in interaction with fertilizer doses, hence the interest in using improved varieties in agricultural intensification. Indeed, [10] advocated that integrated soil fertility management should be based on the use of improved germplasm, the use of mineral fertilizers and good management of soil organic matter.

Compared to the control, the results show that all treatments had a positive effect on growth and yield parameters and on yields. This demonstrates the poor quality of the soil, confirming the results of [8], who highlighted the poverty of the land in the ENSA area, and therefore the need for fertilization to improve yields. [11] showed that most soils with natural poverty respond positively to different fertility improvement practices. Our results are similar to those of [12], who showed a significant effect of NPK and Urea on millet.

The application of fertilizers using the microdose technique improves growth parameters and grain yield compared to broadcast fertilizer application, which demonstrates the value of this technique. In fact, microdosing concentrates the fertilizer in the root zone, thus encouraging greater harvesting [13] while reducing losses [14]. According to $[15,16,17]$, and [18], the performance of microdosing can be explained by the fact that the location of fertilizers in the superficial horizon colonized by plant roots leads to their proliferation and growth; this allows plants to better capture nutrients and water. This technique therefore makes it possible to make better use of mineral fertilizers by reducing losses as much as possible compared to broadcast fertilizer application. In this broadcast application, the fertilizer is brought to the surface without good coverage, thus exposing it to losses by volatilization or by runoff [19]. Recent studies have shown similar results with millet on sandy soils in Niger [20], as well as with cowpea and sorghum in Mali [21]. The higher heights and larger diameters from stem to crown observed in plots fertilized at the highest microdose rates, particularly the NPK4U dose followed by the NPK3U dose, could be due to the high $\mathrm{N}$ content of the treatments. Nitrogen is one of the major nutrients used by plants. Extracted from the air or the soil, it is the driving force and is used to build all the green parts that ensure the growth and life of the plant [22]. Similar results are obtained by [23] with maize in Congo.

The decrease in $\mathrm{pH}$ in the treated plots corroborates the results of [24] and [1] who reported a decrease in $\mathrm{pH}$ following the application of NPK and urea. The same finding was made by [25] who revealed the acidifying effect of chemical fertilizers on soils in Nigeria. According to [26], this 
acidification following the addition of nitrogen and potassium is explained by the potassium-nitrogen antagonism in Ferralsols.

A decrease in nitrogen is observed in all treatments except NPK4U. This could be justified by the nitrogen concentration of the said formula.

Potassium is mainly contained in the vegetative parts. The restitution of straw therefore provides this element. In our experimentation, after demarriage, we left the unmarried plants on the plots, which explains the positive rates of variation in potassium observed in the treatments.

When applied, phosphorus can change from a soluble to a solid state, unavailable to the plant. This phenomenon, called retrogradation, intensifies with high temperature and low organic matter content. The organic matter content of our test soil is low, which explains the positive rates of phosphorus variation obtained in the treatments.

\section{Conclusion}

The results of this study assessed the performance of the microdose technique in improving maize productivity. Indeed, these results show that the application of mineral fertilizers by microdose increases grain yields compared to the control and broadcast application of fertilizers.

This increase in yield is all the more important since NPK is associated with urea.

Although the highest yields are obtained with NPK combined with urea (NPK2U, NPK3U, NPK4U), these are not significantly different from those obtained with NPK alone.

The microdose is economically more profitable than the vulgarized dose regardless of the treatment. The NPK3U treatment produced the highest grain yield $(4.193 \mathrm{~kg} / \mathrm{ha})$ and the highest acceptability index (1.9). However, given the low level of income of our farmers, the NPK2U dose, which had a grain yield comparable to that of the NPK3U treatment and an acceptability index of 1.8 , is the most recommendable. However, as this index is between 1.5 and 2, adoption will be reluctant, hence the need to conduct another study with new microdose options.

The Gwana variety alone or in interaction with the microdose was more successful; however, further experimentation with more varieties is a prospect.

\section{Acknowledgements}

We would like to thank the UMI 3189 "Environment, Health, Societies" (UCAD, CNRS, CNRST, USTTB, UGB), and the Labex DRIIHM, programme "Investments for the future" ANR-11-LABX-0010, for funding our work.

The authors are thanful the University of Thies for the facilities placed at our disposal during the implementation of the field experiment, and the National Institute of Pedology in Dakar for their inputs in the laboratory analysis.

\section{References}

[1] Kaho, F., Yemefack, M., Feujio, P. T. and Tchantchaouang, J. C. (2011). Effet combiné des feuilles de Tithonia diversifolia et des engrais inorganiques sur les rendements du maïs et les propriétés d'un sol ferralitique au Centre Cameroun. Tropicultura, 29 (1): 201-221.

[2] Nyembo, K. L., Usenu, S. Y., Mpundu, M. M., Bugeme, M. D. Kassongo, L. E. and Baboy, L. L. (2012). Effet des apports des doses variées de fertilisants inorganiques (NPK et Urée) sur le rendement et la rentabilité économique des nouvelles variétés de Zea mays L. à Lubunbashi, sud-est de la RD Congo. Journal of applied biosciences 59: 4286-42-96.

[3] Sanders, J. H. and Garcia J. C. (1993). The economics of stress and technology development in the Sahel and the "Cerrados"of Brazil. Proceedings of workshop on Adaptation of Plants Stresses. University of Nebraska, Lincoln, Nebraska. INTSORMIL Publication No 94-2.

[4] Feller, C. (2007). Les sols tropicaux en semis direct sous couvertures végétales. Communiqué de presse (CD rom). Séminaire international à Madagascar 2007.

[5] Le Houérou, H. N. (1989). The grazing land ecosystem of the african Sahel. Ecological studies 75, Spring-Verglag, Berlin (Allemagne), 282p.

[6] Sarr, B., Ndjendole S., Diouf, O., Diouf, M. and Roy-Macauley H. (1999). Suivi de l'état hydrique du sol et de la température du couvert de maïs au Sénégal. Sécheresse, 10 (2), 129-135.

[7] Guéye, M. (2000). Evaluation des besions en eau, de la croissance et de la productivité de 7 variétés de sésame (Sesamum indicum L.) en zone semis-aride du Sénégal. Mémoire d'ingénieur agronome, ENSA, Thiès (Sénégal), 74p.

[8] Abdoulaye, M. D. (2014). Effet de la densité de semis sur la croissance et la productivité de 13 variétés hybrides de maïs (Zea mays L.). introduites en zone semi-aride du Sénégal. Mémoire de fin d'étude. Ecole national supérieure d'agriculture de Thies, UT. 58p.

[9] Zante, P. (1983). Etude pédologique du domaine de l'INDR (Institut National du Développement Rural), Thiès (Sénégal) + Notice et carte de végétation, ORSTOM, 129p.

[10] Alley, M. M. and Vanlauwe, B. (2009). The role of fertilizer in integrated plant nutrient management, IFA and TSBF-CIAT, Paris, France, 59p.

[11] Ouattara, K., Ouattara, B., Nyberg, G., Sedogo, M. P. and Malmer, A. (2007). Ploughing frequency and compost application effects on soil infiltrability in a cotton-maize (Gosypium lhirsutum - Zea mays L.) rotation system on a Ferric Luvisol and a Ferric Lixisol in Burkina Faso. Soil \& Tillage, 95: 288-297.

[12] Diallo, M. D., Diaité, B., Diédhiou, P. M., Diédhiou, S., Goalbaye, G., Doelsch, E., Diop, A. et Guissé, A. (2019). Effets de l'application de différents fertilisants sur la fertilité des sols, la croissance et le rendement du mil (Pennisetum glaucum (L.) R. Br. dans la Commune de Gandon au Sénégal. Revue Africaine d'Environnement et d'Agriculture, 2 (2): 7-15.

[13] Bandoum, Y. P. (2005). Effets de la fertilisation par micro dose sur la productivité du mil, les bilans des nutriments et de l'eau du sol au Niger. Mémoire de fin d'étude. Faculté d'Agronomie, UAM. 57p. 
[14] Muehlig-Versen, B., Buerkert, A., Bationo, A. and Roeheld, V. (2003). Phosphorus placement on acid arenosol of the west African Sahel. Experimental Agriculture 39: 307-325.

[15] Brück, H., Sattelmacher, B. and Payne, W. (2003). Varietal differences in shoot and rooting parameters of pearl millet on sandy soils in Niger. Plant and Soil, 251: 175-185.

[16] Hodge, A. (2004). The plastic plant: root responses to heterogeneous supplies of nutrients. Newphytologist, 162: 9-24.

[17] Vadez, V., Krishnamurthy, L., Kashiwagi, J., Kholova, J., Devi, J., Sharma, K., Bhatnagar -Mathur, P., Hoisington, D., Hash, C. and Bidinger, F. (2007). Exploiting the functionality of root systems for dry, saline, and nutrient deficient environments in a changing climate. Journal of SAT Agricultural Research, 4: $1-61$.

[18] Aune, J. B. and Bationo, A. (2008). Agricultural intensification in the Sahel - The ladderapproach. Agricultural Systems, 98: 119-125.

[19] Adama, T., Louis, Y., Da, I. A. N., Karim, T., Pascal, B., et Ouola, T. (2019). Utilisation du tourteau de neem (Azadirachta indica) et de la micro-dose d'engrais minéraux pour la production du maïs en zone Sud-soudanienne du Burkina Faso. Int. J. Biol. Chem. Sci. 13 (6): 2618-2626.

[20] Ibrahim, A., Abaidoo, R. C., Fatondji, D. and Opoku, A. (2015). Hill placement of manure and fertilizer micro-dosing improves yield and water use efficiency in the Sahelian low input millet-based cropping system. Field Crops Research, 180: 29-36.

[21] Bagayoko, M., Maman, N., Palé, S., Sirifi, S., Taonda, S., Traore, S. and Mason, S. (2011). Microdose and N and P fertilizer application rates for pearl millet in West Africa. African Journal of Agricultural Research, 6: 1141-1150.

[22] FAO, (2005). Notions de nutrition des plantes et de fertilisation des sols. Manuel de formation, projet intrants, Niger, $24 \mathrm{p}$.
[23] Lucien, N. K., Ilunga, T. H., Emanuel, M. M., Augustin, E. O., Mick, A. B. L., Antoine, K. L., Michel, M. M. and Louis, B. L. (2014). Influence de la fertilisation à base des déchets humains recyclés, des engrais minéraux et de leur combinaison sur le comportement de 3 variétés de maïs (Zea mays L.). Journal of applied Biosciences, 77: 6500-6508.

[24] Saragoni, H., Poss R., Marquette J. and Latrille E. (1992). Fertilisation et succession des cultures vivrières au sud du Togo: synthèse d'une expérimentation de longue durée sur terre de barre.

[25] Uyo, Y. E. O. and Elemo. K. A., (2000). Effect of inorganic fertilizer and foliage of Azadirachta and Parkia species on the productivity of early maize, Nigerian Journal of Soil Research, pp. 17-22.

[26] Bekunda, M. A., Bationo, A. B. and Ssali, H. (1997). Soil fertility management in Africa: are view of selected research trials. chemical diversity and distribution of glucosinolates and Isothiocyanates among plants. Corrigendum Phytochemistry, 59: 200-237.

[27] Greg, M. E. (2008). Effect of enzymes on cellulose, European Journal of Applied Microbiology Biotechnology, 40: 167-171.

[28] Onunkwo, D. N and George, O. S (2015). Effects of Moringaoleifera leaf meal on the growth performance and carcass characteristics of broiler birds. IOSR Journal of Agriculture and Veterinary Science, 8 (3II): 63-66.

[29] El Tazi, S. M. A. (2014). Effect of feeding different levels of Moringa oleifera leaf meal on the performance and carcass quality of broiler chicks. International Journal of Science and Research, 3 (5): 147-151.

[30] Bakary, D., Mariama, D. D., Touroumgaye, G., Siré, D., Abdourahmane, D., RAMATA, T., Aliou, D. et Aliou, G. (2020). Effet de l'application de différentes doses de fertilisants organiques sur la croissance et le rendement de la tomate (Solanum lycopersicum L.) en conditions semi-contrôlées. Journal of Animal \& Plant Sciences, Vol. 44 (1): 7553-7566. 